\title{
Religion, Nonreligion and the Sacred: Art and the Contemporary Rituals of Birth
}

\author{
Anna M. Hennessey
}

Citation: Hennessey, Anna M. 2021. Religion, Nonreligion and the Sacred: Art and the Contemporary Rituals of Birth. Religions 12: 941. https:// doi.org/10.3390/rel12110941

Academic Editors: Joanna Wojtkowiak and Brenda Mathijssen

Received: 1 October 2021

Accepted: 26 October 2021

Published: 29 October 2021

Publisher's Note: MDPI stays neutral with regard to jurisdictional claims in published maps and institutional affiliations.

Copyright: (C) 2021 by the author. Licensee MDPI, Basel, Switzerland. This article is an open access article distributed under the terms and conditions of the Creative Commons Attribution (CC BY) license (https:// creativecommons.org/licenses/by/ $4.0 /)$.
Berkeley Center for Study of Religion, University of California, Berkeley, CA 94720, USA; amhennessey@berkeley.edu or amhennessey@gmail.com

\begin{abstract}
This paper looks at the role of art and material culture in the rituals of birth, first taking into consideration research on material culture in traditional rituals of birth and then turning to the primary topic, which is how art in the contemporary rituals of birth often holds sacred meaning even when the ritual is of a nonreligious nature. A discussion about the sacred in the context of a nonreligious ritual hinges upon an understanding of that which is "sacred"; thus, the paper looks at research on modern theology and the sacred to examine the term in the context of birth as a contemporary rite of passage. Giving examples of how material culture has been important in several traditional birth rituals from different cultures, the paper then traces a similar occurrence in which participants in contemporary nonreligious rituals of birth also uphold art and material culture as sacred elements of the rituals. The paper provides the reader with description of a rich array of art and material culture used across cultures in different rituals of birth. Taking into consideration the numerous contributions that scholars have made to the emerging field of birth and religion, including the interdisciplinary importance of theories related to birth as a rite of passage, the paper also presents new research on the materiality of the contemporary rituals of birth.
\end{abstract}

Keywords: African birth ritual; ancestor worship; art; birth; birth altar; birthing justice; ceremony; child; childbirth; Chinese birth ritual; contemporary art; humanism; indigenous birth ritual; material culture; mother; nonreligion; nonreligious; pregnancy; religion; re-sacralization; rite of passage; ritual; sacred; secular; secularity; spirituality; symbol; traditional birth

\section{Introduction}

This paper looks at the role of art and material culture in the rituals of birth, first taking into consideration research on material culture in traditional rituals of birth and then turning to the primary topic, which is how art in the contemporary rituals of birth often holds sacred meaning even when the ritual is of a nonreligious nature. A discussion about the sacred in the context of a nonreligious ritual hinges upon an understanding of that which is "sacred"; thus, the paper looks at research on modern theology and the sacred to examine the term in the context of birth as a contemporary rite of passage. Giving examples of how material culture has been important in several traditional birth rituals from different cultures, the paper then traces a similar occurrence in which participants in contemporary nonreligious rituals of birth also uphold art and material culture as sacred elements of the rituals. The paper provides the reader with description of a rich array of art and material culture used across cultures in different rituals of birth. Taking into consideration the numerous contributions that scholars have made to the emerging field of birth and religion, including the interdisciplinary importance of theories related to birth as a rite of passage, the paper also presents new research on the materiality of the contemporary rituals of birth.

In her seminal work on ritual, Ritual: Perspectives and Dimensions (Oxford University Press, 1997), religious studies scholar Catherine Bell states that the ways in which a traditional society experiences birth ritualistically influences that society's development of other ritualistic traditions (95). Traditions that stem from a culture's birth rituals, including 
rituals related to death, emphasize how material objects are integral to the way that the meaning of the rituals is conveyed to the participants and observers.

This paper briefly examines a few such examples from different traditions. The intent here is to first demonstrate the point that Bell makes about the impact that birth rituals can have on the development of other cultural forms and ritual life. The cases cited have been chosen because they offer concrete examples of how traditional rituals of birth have an impact on a society's development of other ritualistic traditions. After that, the paper turns to a discussion of the contemporary rituals of birth, looking both at how religious objects have the capacity to become re-sacralized in a new way during birth as a rite of passage, as well as at how nonreligious objects become sacred of their own accord.

\section{Results}

\subsection{Material Culture in Traditional Rituals of Birth}

Ethnographic studies such as those conducted by the late anthropologist Gene Cooper (1946-2015), a professor and scholar who worked extensively on Chinese folk customs, provide a view into how birth rituals are highly influential to a culture's other ritualistic traditions. Cooper's research on the rituals of birth and other life cycle rites of passage as they occur in the context of Dongyang County, China, shows the strong influence that birth rites can have on a culture's other rituals. In the context of Dongyang culture, beginning with birth, all life-cycle rituals are focused on a theme related to longevity and a Chinese concern with the extension of mortal time: "One begins life with a longevity bowl secreted under the bed. One eats longevity noodles on birthdays and receives longevity couplets and longevity scrolls on 'big birthdays'" (Cooper 1998, p. 391). Historically, during China's late dynastic times, the woman's placenta was also placed in a clay pot underneath the bed, where it would stay until the child was grown up, a symbol of fertility (Cooper 1998, p. 375). This same theme of longevity and the extension of human mortality continues well past birth, shadowing people as a living motif throughout their ritual lives:

"One is buried in longevity clothes, in a coffin called a longevity box, decorated with the longevity character, and guests eat longevity rice at funerals. Women receive a longevity quilt on occasion of marriage. Chinese seem to be obsessed with extending the limits of human mortality, which while thus clearly recognized are at once mystified into nonrecognition in the ancestral cult and its rituals of death. The metaphor of the noodle as a longevity food suggests a conception of time similar to that of the West, and eating noodles to lengthen life is among a variety of ritual and symbolic measures and plays on words employed to influence fate and evade ill fortune; e.g., choosing auspicious days and times, marrying spirits, linking bags, serving peanuts, and begging" (391).

It is easy to note that in all of the rituals Cooper mentions, material objects are integral to the process of conveying the message of the ritual to those involved. The rituals cannot be separated from these objects-bowls, noodles, couplets, clothes, coffins, etc., the material means through which the ritual is performed. Cooper's research shows the extent to which the theme of longevity is embedded in the cultural understanding of mortality and in all life-cycle rituals in Dongyang, beginning with the longevity bowl and noodles after birth.

The case of Dongyang provides a good example of Bell's claim that themes embedded in the rituals of birth become infused in other rituals experienced by humans and their communities throughout the course of life, particularly in the context of traditional societies. The research also shows how material objects are central to ritualistic practices in their traditional context.

Herbert Cole's Maternity: Mothers and Children in the Arts of Africa (Cole 2017) is extensive and provides numerous images of mothers and children as they occur across different timeframes in Africa. Cole shows how these mother-child images have maintained an ever-present existence in Sub-Saharan Africa across time and up through to modern and contemporary age representations. The objects are not mere representations of mothers and children, however, but are an important part of the fabric of African belief and ritual 
action, tied to the sacred emphasis in the lives of African women to conceive and give birth. The images, while indeed connected to birth and mothering, are also a foundational part of the rituals of life in Africa.

In "Exploring Motherhood in African Arts," a 2018 article for İMỌ’ DÁRA, a magazine and single site resource for African art. (Cole 2018) Cole also provides abundant information on the material culture of motherhood in Africa. Maternity figures and motherand-child imagery are central to the article, and Cole describes them as integral to African ritual life and in some contexts to life itself. Ala, "Earth," for example, is a maternal earth figure and important deity for the Owerri Igbo located in southeastern Nigeria. As Cole describes, "She is the true 'ground of being' for Owerri people, the font of both fertility and morality, the source of tradition and therefore, culture." Numerous rituals are connected to the deity, and as Cole explains in the section of the article titled, "Mbari: Art as Process in Igboland," large clay sculptures of the maternal figure Ala are found alongside smaller sculptures of children in mbari, which are sculpture-filled houses devoted to the deity. The deity is not just a fertility figure but is also connected to a rich variety of ritual and cultural life for the Igbo community.

Researchers at the Maryknoll Institute of African Studies (MIAS), located in Nairobi, Kenya, have conducted studies on pregnancy and birthing rites and rituals in the context of East African culture. The research on these rituals, found in Michael C. Kirwen's work, African Cultural Domain No.1: Pregnancy and Birth (Kirwen 2004), is a booklet in a series of fifteen. Similar to Cole's work, Kirwen's research shows that the rite of passage of birth in the context of African society is intimately bound to the broader cultural reverence for the ancestral spirits, and the theme of birth as connected to the ancestors is carried through the rituals of an individual's life, including those rituals associated with marriage and death. The rituals around birth, including proper disposal of the placenta, also have an impact on the future of the person and of the community (Kirwen 21).

Yet another scholar working in the context of traditional African birth rituals, Ogechukwu Ezekwem Williams, has also recently shown how in pre-colonial Nigeria, the traditions of birth were influential in the larger ritualistic traditions of Igbo culture and spirituality. As part of this continuation of ritual from the birth event was the increased spiritual role that women attained when they became new mothers. Perceived as imbued with spiritual powers after giving birth themselves, these women claimed new communal roles, which included the overseeing of fertility rituals and the partaking in midwifery practices themselves; thus, a cultural pattern stemmed from the event of birth, and women who gave birth became crucial participants in future rituals related to fertility and birth ( Williams 2018, p. 104). Williams explains how British colonialism ruptured the wholeness of this ritual life when missionaries changed the primary birthing space of Igbo women to that of the hospital. However, contemporary birth practices have begun to reincorporate spirituality and tradition into the rite of passage.

\subsection{Theories of Rites of Passage: From the Traditional to the Contemporary in the Rituals of Birth}

This paper now shifts attention from these traditional birth rituals to those of a secular or nonreligious setting found in many contemporary rituals of birth. A growing number of scholars have looked at the sacred in the contemporary rituals of birth. Some of these scholars include Alicia D. Bonaparte, Melissa Cheyney, Susan Crowther, Robbie DavisFloyd, Marianne Delaporte, Ann Duncan, Jenny Hall, Pamela Klassen, Morag Martin, Julia Chinyere Oparah, Arisika Razak, and Joanna Wojtkowiak. The research of this paper specifically explores how the meaning of art and other material objects has the capacity to become sacred or re-sacralized in the context of the contemporary rituals of birth, similar to how art and objects become sacred in the context of traditional birth rituals, which are of a religious nature.

In Birth as an American Rite of Passage (University of California Press, 1992), cultural anthropologist Robbie Davis-Floyd famously describes a highly ritualistic nature as inherent in the technocratic model of an American hospital birth. Influenced by the extensive body 
of work on rites of passage developed during the early and mid-twentieth century, found in the research of scholars such as French ethnographer and folklorist Arnold van Gennep (1873-1957), and British anthropologist Victor Turner (1920-1983), Davis-Floyd contends that even when secularized, contemporary rituals of birth resemble rituals attached to birth in traditional societies.

Looking briefly at Arnold van Gennep's classic model for the processes that make up a rite of passage as found in his major work, The Rites of Passage (van Gennep 1960 [Les Rites de Passage, 1909]), one notes that the model is characterized by a subdivision of the rite into three distinct stages: rites of separation, transition rites, and rites of incorporation (van Gennep 1960, p. 11). During the first phase, the individuals are separated from the identity held in their previous social states. The second stage represents a liminal phase during which time individuals exist neither in their former nor their future social states. The final stage, the rite of incorporation, represents a period during which the rite has been completed and the individual reenters society with a new sense of identity.

In the context of childbirth as a rite of passage and her study on pregnant women, Davis-Floyd describes early pregnancy, when a woman first realizes and fully acknowledges that she is pregnant, as the transition phase (Davis-Floyd 1992, pp. 22-23). The transition, or liminal phase, according to Davis-Floyd, is the longest period in the rite, encompassing the bulk of time during which the woman is pregnant, her experience of labor and childbirth, and the immediate postpartum period (23-41). The final phase of the rite, that of incorporation, happens gradually over the first few months of the newborn's life, at which point the woman is integrated into society as a new mother (41-43).

In Blessed Events (Princeton University Press, 2001), religious studies scholar Pamela Klassen points out that some feminist scholars have been critical of van Gennep's tripartite division of the rite of passage, which they see as too universalizing and andocentric of the human experience (Klassen 2001, p. 85). In the cases that she studies, Klassen agrees to some extent with this criticism of van Gennep, stating that for a number of the North American women at the heart of her study, the ritual of birth is one of intensification and not of a reversal of social position (85). However, Klassen still understands van Gennep's work on rites of passage as an important contribution to our understanding of the transformations that humans make during these rites, which are of a social nature and not just a physical one (85).

In the case of the art and material objects at the heart of my research, van Gennep's categories are relevant but of less significance in that the objects of discussion may become sacred before, during, or after the ritual of birth. Their sacredness is not necessarily dependent upon the physical status or social stage of the individuals involved. Rather, these individuals determine the meaning of the objects as sacred based on any of a number of factors and personal experiences that take place before, during, or after birth, or even before pregnancy. If a woman experiences issues with fertility, for example, then a particular charm or pendant may take on a different sense of the sacred than does the same object for a woman who is preparing for labor, or for another woman who has just given birth.

Influenced by the symbolic anthropology of Clifford Geertz, Davis-Floyd also emphasizes the crucial role that symbols play in transmitting the message of the ritual—both to the performers and to the receivers of that ritual (Davis-Floyd 1992, pp. 9-10; Geertz 1973). Objects used during birth, including items such as hospital gowns and instruments, she contends, can take on ritualistic import during the process of birth. Medical anthropologist Melissa Cheyney, who is also a midwife, has similarly researched how objects such as birth tubs used in homebirths also act crucially as symbols for participants during the ritual of birth (Cheyney 2011, pp. 535-36).

We can trace how across various historical, social, and cultural contexts, material objects that are part of the birth process become emotionally charged and ritualistically meaningful to women and participants before and after pregnancies, as well as during birth. Expanding on this assessment, this paper proposes that art and other objects associated with birth, whether they stem from a religious origin or are of a nature that is entirely 
nonreligious, have the capacity to become sacred of their own accord. These material objects play a part in revering birth as a sacred event, and it is in this reverence for birth, and for mothering or parenting as well, that nonreligious objects become sacralized and treated as devotional items to be used in conjunction with birth as a sacred ritual.

I now turn to look at certain art and other objects used in the contemporary rituals of birth. It is through the rituals that these objects have the capacity to become sacred in a new way, transformed by their users.

\subsection{Birth Art, the Sacred, and the Contemporary Rituals of Birth}

Curiously, there are few representations of women giving birth found across the entire timeline of art history. This fact becomes particularly salient when comparing the large number of art images of death across time to the small number of art images of birth. Whether this dearth of birth imagery has to do with an original lack of interest in the subject or with a destruction of birth images that has occurred over the course of history is a topic of interest but will not be discussed here. I do discuss this issue at length in my work (Hennessey 2017, 2018). What is addressed here is the flourishing of so-called "birth art" in the twenty-first century, its relationship to new understandings of birth as a sacred act in itself, and the formation of nonreligious rituals of birth in which art is of central interest.

By the early 2000s, contemporary art and artisanship about pregnancy, birth, mothering, and parenting began to flourish, spreading across the internet through image sharing and online galleries, as well as on the ground in small gallery exhibitions. With a few exceptions, many of the artists creating this work are still not widely known. Their art is increasingly recognized within birth and midwifery communities around the globe, however, and there is a growth of interest in the work, some for its artistic merits alone. Since 2010, I have been collecting images of birth available online through an archive called Visualizing Birth (www.visualizingbirth.org, Hennessey 2010). The archive has in turn become a resource for those in the birth community while also providing me with interesting data on the types of images that those in the community are seeking out, utilizing, and creating. Google Analytics and other tracking services for the archive show me, for example, from which countries and locations visitors are coming, as well as the search terms that they use. Over the past decade, visitors to the site have come from a large number of countries across six continents around the world (Africa, Asia, Australia, Europe, North America, South America), pointing to the transnational and transcultural nature of using images in birth as a contemporary rite of passage.

This paper examines one primary aspect of these contemporary pieces, which is how the artists and artisans who are creating the work invite their viewers to enter the works with an understanding that the events depicted are sacred. In these works, the sacred and the secular merge, creating a new visual form of nonreligious sacrality as integral to the meaning of the objects. In conveying the meaning of the artworks to their viewers, these artists often explain the symbolic function of the art as related to an expression of birth as a sacred act, typically of a nonreligious or humanistic nature, even in those cases in which religious iconography is utilized. Before turning to the works, however, this paper briefly looks at theories of the sacred, and how something may be both nonreligious and sacred at the same time.

Gordon Lynch's theory of a sociology of the sacred, which itself stems from French sociologist Émile Durkheim's theories of a sacred-profane dichotomy at the heart of human experiences of religion and the world, is helpful in determining the difference between that which is "religious" and that which is "sacred." Lynch, a professor of modern theology, has worked extensively on the topic of a sociology of the sacred, differing the sacred in this context from how it might be found within a sociology of religion. While forms of religious life, including the ways in which practices, ideas, objects, and symbols are associated with religion have a wide sociological variety, so do cultural forms of the sacred. In The Sacred in 
the Modern World: A Cultural Sociological Approach (Oxford University Press, 2012), Lynch determines that these cultural forms exist separately from forms of religious life:

"While there is clearly a degree of overlap between these two sociological projects, there are also important differences. Contemporary sacred forms often have a significant religious past, and sacred forms associated with particular religious traditions and communities play a part in the multiplicity of sacred forms within contemporary society. But the wider range of sacred forms that exert considerable influence over contemporary life cannot be easily encapsulated within the concept of 'religion'" (6).

Lynch emphasizes how understanding the sacred forms of contemporary life entails not conflating them with forms of religious life, even though there may be some overlapping of the two:

"Gender, human rights, the care of children, nature, and the neo-liberal marketplace all have sacralized significance in modern social life, but our understanding of the nature and operation of these sacred forms is not helped by framing these as 'religious' phenomena" (6).

Lynch's theory of a sociology of the sacred offers an understanding of the sacred as a rich category inclusive of many cultural forms that, while not religious, are special in a unique way that demarcates them from the sphere of the profane. In his book On the Sacred (Lynch 2012), Lynch explains that the sacred goes beyond that which is attributed high value by an individual or a community, and is rather, "a way of communicating about what people take to be absolute realities that exert a profound moral claim over their lives" (11) or "the meaning of fundamental realities around which our lives are organized" (26). Lynch studies different types of sacred forms across culture and history. One form that he finds prevalent in modern thought and policy is the sacredness of humanity, of being human (83). This form of the sacred developed during the last half of the eighteenth century, contends Lynch, when theories of universal human rights began to flourish in philosophy and political thought, leading eventually to the mid-nineteenth century to present day rise of humanitarian organizations (85-86).

I maintain that the way in which art and other objects become sacred when participants use them during the contemporary rituals of birth rests in communal agreement that birth is an important if not foundational act in the human experience. Agreeing with Lynch again along Durkheimian terms, I contend that the sacred involves transcendence of mundane reality. Used ritualistically during birth, art and other objects become a transcendent part of the ritual, understood as sacred both personally by individuals as well as through a shared social reality connecting individuals who share in their devotion to the birthing process.

\subsection{Sacred and Re-Sacralized Objects in the Contemporary Rituals of Birth}

Over the past twelve years, I have researched a wide variety of art, imagery, and other objects used in birth as a rite of passage. For the purposes of this paper, I have selected a small number of these art objects. Many more may be viewed on the Visualizing Birth website or in my book, Imagery, Ritual, and Birth. Here, the paper looks at five objects, some of which stem from an original religious context and have been re-sacralized in the context of birth, and others of which become sacred in their humanistic connection to birth as a rite of passage.

\subsubsection{Pachamama}

The first art object discussed is that of Pachamama (Figure 1), or "Earth Mother," a female goddess representing fertility and abundance in Inca mythology. I look briefly at the origins and history of the Pachamama figure, as well as how participants in birth as a rite of passage utilize the figure in the contemporary rituals of birth. 


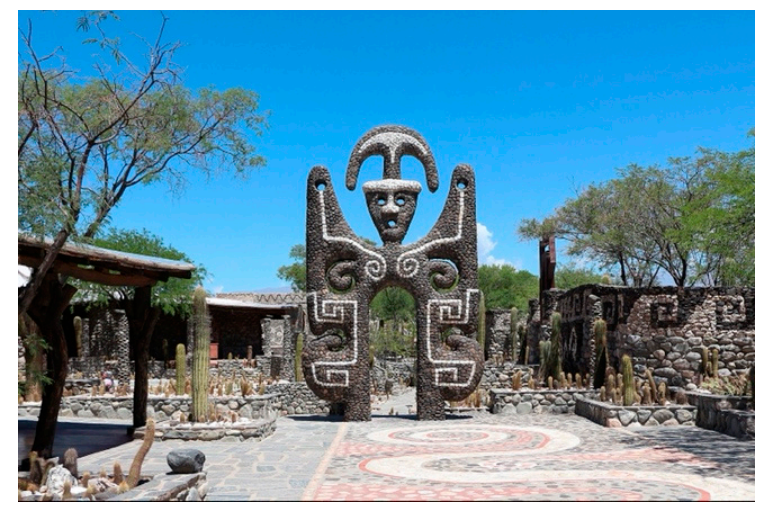

Figure 1. Pachamama, Pachamama Museum, Amaicha del Valle, Argentina. Photo by Bernard Gagnon, copyright 2018 Wikimedia Commons (Creative Commons: CC BY-SA 1.0).

Even after the Spanish conquest of the Inca Empire during the sixteenth century, representations of Pachamama were preserved and continue to permeate Andean culture, found in the contexts of art, religion, and everyday life. Pachamama is in fact the central figure of Andean religion today, viewed as the earth itself and therefore as the nurturer of life, but also as connected to death through the earth's power to kill through natural disasters such as lightning and earthquakes (Bolin 1998, p. 32). She is also acknowledged within this same cultural context as an intercessor against evil or of the devil, and is the focus of rituals utilized for protection (Taussig 2010, p. 208). When it comes to actual childbirth, Pachamama in this same original cultural context has a direct connection to the event. She is seen as the figure that gives children spiritual life after birth, as well as the one that will eventually take humans back into the womb when they die (Bolin 2006, p. 29).

During the colonial period of the sixteenth, seventeenth, and eighteenth centuries, some artists in Peru represented Pachamama as encompassing the body of a mountain while also merging her image with that of the Virgin Mary (Black and Gravestock 2003, p. 189) This style developed from within the Cuzco School of Peru, a Roman Catholic tradition of painting through which indigenous artists such as Quechua painter Diego Quispo Tito (1611-1681) used some European painting techniques while also merging Christian subject matter with that of their own symbolic imagery of Andean sacred landscape (see, for example, the Virgen del Cerro, an eighteenth-century painting by an anonymous artist, currently located at the Museum Casa Nacional de Moneda, Potosì, Bolivia).

In the context of a contemporary birth community, images of Pachamama and references to her are often associated with the act of birth itself. Sorayya Kassamali Rickicki, a New York City student midwife, doula, lactation consultant, prenatal yoga teacher, and mother of three, for example, has incorporated the name "Pachamama" into the name of her company, "Pachamama Birth," which provides birth doula and lactation services (Kassamali Rickicki 2017b). Of Tanzanian and Ecuadorian heritage, Kassamali Rickicki describes a heritage of birth knowledge as having been passed to her through her female relatives when she was a girl.

In my correspondences with Kassamali Rickicki, which date to 2017, she explains the symbolic importance of Pachamama in relationship to pregnancy and birth, describing her personal use of the figure's symbolism in her practice. She is similarly interested in other religious symbolic functions, even though she does not have her own religious beliefs associated with the symbols:

I chose Pachamama because I am of Ecuadorian heritage and Pachamama is an important symbol in Andean indigenous culture. It loosely translates as "Mother Earth," and has a powerful significance in relation to birth ... I don't have any religious beliefs associated with the word or the imagery but I like what it represents and I use it along with other imagery on my site. I have integrated that imagery with a Dhamma Wheel, pregnant body, lactating breasts, etc. because it all symbolizes the circle of life and the birth of all things." 
Kassamali Rickicki re-sacralizes Pachamama when utilizing the figure with pregnant clients. For her, the symbolic function of the traditionally religious image relates specifically to childbirth. She focuses on Pachamama as a sacred birth figure and emphasizes the figure's connection to the act of birth.

In a medical article about the history of different positions for labor and birth used across cultures, Cuban doctors Miguel Lugones Botell and Marieta Ramirez Bermudez make reference to the figure of Pachamama, although not for the purposes of explaining her religious signification. Rather, they show an image depicting a woman who squats while giving birth to a crowning baby (Lugones Botell and Ramirez Bermudez 2012). The purpose of their article is not to advocate any one position for labor or for birth, but to describe the different practical benefits of all birthing positions, including vertical and seated positions, as well as those that a woman uses when she receives an epidural or other medical intervention. The article includes three other images, each coming from a different cultural, religious, and historical context. These include a picture of the Aztec deity, Tlazolteotl, an Ancient Roman relief of a woman giving birth, and an ancient ceramic piece from Peru's Moche Culture (Lugones Botell and Ramirez Bermudez 2012). In each case, the focus of the authors' data is on the actual positioning of the body used during birth.

The same image from the Cuban medical journal is subsequently referred to in several Spanish-language articles on birth and mothering. All of these are written for a popular audience and focus not on religion but on ideal positions for women to use during labor and childbirth (Paris 2011, 2017).

One of the most popular images of Pachamama used across the web is a small watercolor and pen drawing that depicts the goddess smiling with a baby shown upside down and ready to be born. The artist who created the image is unknown and thus publication of the work is therefore not possible due to copyright laws (please see: visualizingbirth.org/pachamama-fertility-goddess-and-mother-earth). The image is found on over one hundred websites, including English- and Spanish-language pages about birth, as well as social art files such as those found on Pinterest and Tumblr. The main topic on many of these websites is devoted specifically to birth and to providing women with information on birth positioning or to promote positive images of the event. Most of the sites do not describe the image other than to name it as an image of Pachamama. The image appears, for example, numerous times on Pinterest on pages that offer the viewer a look at art imagery of birth. Websites focusing on birth art and the use of art for childbirth purposes also frequently include the image.

On the Global Economic Symposium blog (GESblog), the same image also appears in the article titled, "How to empower women through religion" by Brazilian journalist Yohana de Andrade (de Andrade 2014). In this case, the author makes a direct connection between the religious origins of Pachamama, as well as to the religious origins of other female deities, emphasizing how knowledge of these figures relates to a sense of empowerment for women. The writing transforms the meaning of the Pachamama figure from the sphere of religion to a broader and more secular understanding of Pachamama as a representation of empowerment for women.

In the case of Sorayya Kassamali Rickicki, the owner of Pachamama Birth discussed earlier, she includes Pachamama as one symbolic religious figure among others (such as the dhamma wheel), for example, to be used by women as they connect more deeply to the cycle of life and prepare for birth as a rite of passage (Kassamali Rickicki 2017a, correspondence). While these connections may not be of a religious nature, they are woven with an understanding that the physiological passage of birth is a sacred passage.

It is worth noting that Kassamali Rickicki has worked with a wide variety of women in the New York City area. In addition to her clients from the United States, she has served women from West Africa, Mexico, the Dominican Republic, Ecuador, and Colombia. Other women she has helped through the birth process include new immigrants, orthodox Jewish women, single mothers, and women on Medicaid (Kassamali Rickicki 2017a, correspon- 
dence). These demographics are important, contributing to data that suggest a variety of women of different racial, ethnic, religious, and socioeconomic backgrounds are utilizing images during the rituals of birth.

Different Pachamama figures and images are found for use or purchase through various vendors. Shawna Hawk Rose, one such artist and vendor, sells small Pachamama statues that she makes out of clay and other materials. The figurines are marketed as pieces to use as gifts within the birth community or in honor of birth and conception. Yet as in the previous cases, the meanings of these objects are not understood as existing within a secular vacuum from which the sacred has been removed. Instead, the object is identified with the sacred. This sacredness, however, is understood primarily through its associations with birth and the divine feminine and not with the sphere of religion.

The use of the name "Pachamama" occurs elsewhere within today's birth community, found readily online, including for doula, midwifery, prenatal care, and other services related to pregnancy and birth. These contemporary usages involving Pachamama, the religious and cultural figure, often emphasize the Incan goddess as a powerful female figure who connects women to an inner or spiritual self in relationship to fertility and the rituals of birth.

\subsubsection{The Woman of Willendorf}

Other objects associated with religious cultural life are similarly re-sacralized in the context of the contemporary rituals of birth. Some of the earliest forms of sculpture known to humankind are found in a type of statuette created by the Gravettian culture, which existed between 28,000-20,000 BCE and was located most prominently in what is today central Europe. These small statues are made of limestone and depict the female body in the full round (de la Croix et al. 1991, p. 36). Archaeologists have in the past referred to these figurines as "Venus Figures," considering the objects to have symbolized fertility for ancient peoples of the Old Stone Age. The most famous of these statuettes is the "Woman of Willendorf" (also called the "Venus of Willendorf") (Figure 2). Standing $41 / 8$ " tall, the Woman of Willendorf displays large breasts and hips and belly that are exaggerated in their voluptuousness. Her vulva is also large and full. With no facial features, she does not depict a particular woman but instead represents a symbol, possibly of fertility (de la Croix et al. 1991, p. 36). Although the original purpose of the Woman of Willendorf is still unclear, scholars working on the object and other such figurines hypothesize that the items were associated with ancient fertility beliefs or shamanistic rituals (Wilford 2009).

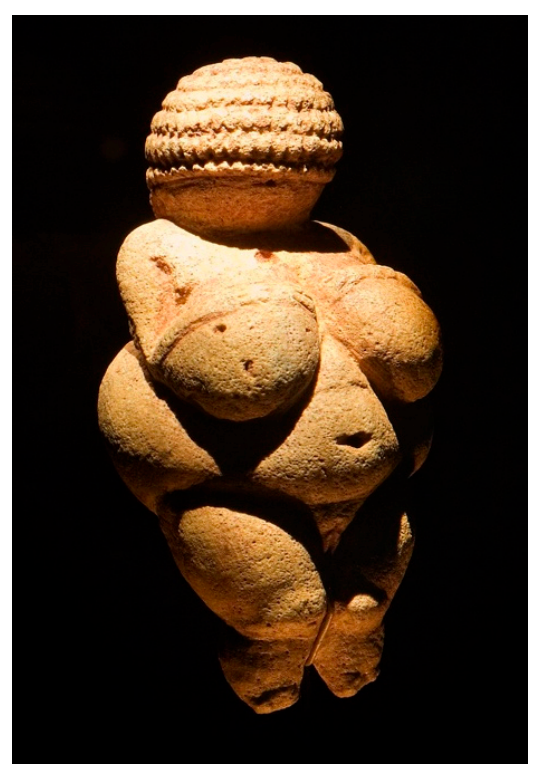

Figure 2. Woman of Willendorf, Willendorf Venus Natural Museum, Vienna, Austria. Photo by Jorge Royan, copyright 2007 Wikimedia Commons (Creative Commons: CC BY-SA 3.0). 
Today, images of ancient goddesses, fertility figures, and objects such as the Woman of Willendorf are found across the web on sites promoting topics related to pregnancy, birth, fertility, and sexuality. On the Birth Matters website, for example, a hub of information on birth in New Zealand, the figurine appears alongside the text that the object simply, "honours women's birthing abilities." As in the case of the Virgin Mary, a mother figure who is widely revered in the birth community but not discussed in this paper, numerous Pinterest pages providing viewers with images related to pregnancy and birth include the Woman of Willendorf. Through Pinterest, visitors can also link out to various shopping websites where they can purchase pendants and jewelry of the Woman of Willendorf as related to childbirth and pregnancy. Similarly, Facebook posts associated with childbirth education, doula, or midwifery service show the figure of the Woman of Willendorf and describe the object as a symbol of fertility and birth.

Numerous items marketed as Woman of Willendorf necklaces, figurines, pendants, and charms are also used in the context of fertility, pregnancy, and birth, often understood as sacred objects. Joanna Hajduk, a Polish artist who creates stone statuettes of the Willendorf figure, for example, describes her recreations as "shamanic figurines," to be used in relationship to fertility or the rituals of birth, and particularly as part of a sacred birth altar. Another artist, Jenna Danielle, sells printable adult coloring pages of the Woman of Willendorf, which she states can be used by women or by doulas who are helping other women prepare for birth as a way of celebrating a woman's own internal "fertility goddess." Other artists create metal or stone charms and jewelry of the figure, selling them through shopping websites such as Amazon and Etsy in the context of sacred birth items. The replicas of the Woman of Willendorf, as well as photos of the original Paleolithic figure, are also found in Pinterest collections devoted to the topic of sacred birth art.

In all of these cases, the meaning of the Woman of Willendorf has gone through a transformation. Its function relates neither exclusively to a religious or cultural history, nor to a secular purpose. Instead, there is a collective understanding within the birth community that the object is sacred in the humanistic context of birth and the contemporary rituals of birth.

\subsubsection{Labyrinths for Birth}

Like Pachamama and the Woman of Willendorf, the labyrinth (Figure 3 ) is an important part of material culture used in the rituals of birth. Unlike a maze, which has multiple sometimes dead-end paths, a labyrinth is unicursal with a single path leading towards a center. Labyrinths have been used for various reasons in numerous cultures over the course of history, identified in the cultural and religious contexts of the Native Americans, Ancient Greeks, Chinese, Scandinavians, South Asia, and Ancient Peru, among others. Yet they are also used in the contemporary context of childbirth. Pregnant women visualize the labyrinth as a sacred path of emergence for both mother and child. In this context, labyrinths represent a mother's emotional and physical passage towards her child and can be used ritualistically by the pregnant woman as she prepares to labor and birth her baby.

Many midwives and others working within the birth community either walk labyrinths with pregnant clients or encourage them to do so on their own. In San Francisco, for example, the city where my own children were born, there are regular practices organized by the Bay Area Homebirth Collective (BAHC) during which time those who are pregnant walk one of the two labyrinths at Grace Cathedral (a large labyrinth inside the cathedral itself or a smaller one located in an exterior courtyard) with midwives, doulas, yoga instructors, and others. Sue Baelen, a licensed midwife and owner of Sacred Body Midwifery in San Francisco, is one of the regular organizers of this activity. Quoting Helen Curry's (2000) trade book, The Way of the Labyrinth (Curry 2000), Baelen's flyers describe the event as a place where, "the spiritual and physical merge into a walking meditation." 


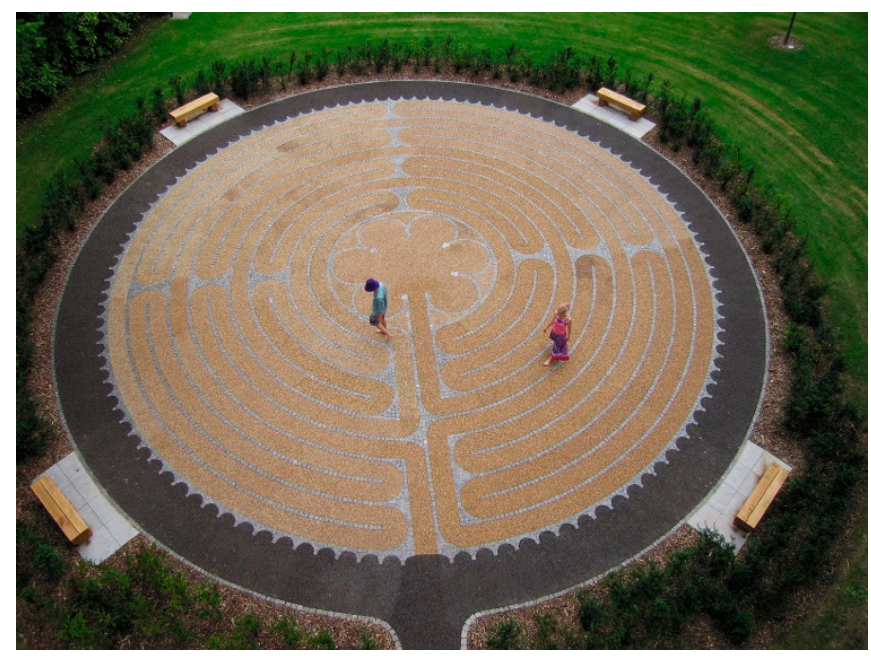

Figure 3. Edinburgh Labyrinth, George Square Gardens, Edinburgh, United Kingdom. Photo by Di Williams, copyright 2008 Wikimedia Commons (Creative Commons: CC BY-SA 3.0).

Pam England, a Certified Nurse Midwife and artist, has written prolifically for a popular audience on the use of labyrinths, mazes, and yantras as a way for those who are pregnant to prepare for labor and birth in a ritualistic way. Her 2010 book, Labyrinth of Birth: Creating a Map, Meditations and Rituals for your Childbearing Year, provides a basic guide to the history of labyrinths in world culture, and describes how visualization of the labyrinth can help pregnant women and people as they prepare for the contemporary rituals of birth. England describes and gives honor, for example, to the symbol of mother and child in the Hopi Tapu-at labyrinth. Tapu'at means "mother and child" (England 2010):

"It is unique because it has two entrances and contains two labyrinths, one within the other. Tapu-at is referred to as "Mother and Child" because the outer labyrinth holds the inner labyrinth, like a mother holding her child. This labyrinth is like the mother's womb enveloping the unborn baby. The unattached center line emerging from the entrance of Tapu'at represents the umbilical cord" (4).

This type of labyrinth is in the shape of a square and symbolizes a pathway between the terrestrial world and the world beyond (Gómez and Carlos 2016, p. 4). Walking the labyrinth, the design of which the Hopi see as similar to the path between mother and child when the child is in the womb, brings the participant from one realm to the other, representing a rebirth (Werness 2000, p. 197). England suggests that such labyrinths may aid in the visualization of birth. England describes the journey that one takes when walking a labyrinth:

"The labyrinth is an ancient, universal symbol representing our journey through life, ordeals and transitions. Its single, convoluted pathway begins at the opening, leads directly to the center and out again. The journey into the labyrinth's center is symbolic of letting go and of death (psychic or physical), and the journey from the center out of the labyrinth represents birth and rebirth. Walking or finger-tracing a labyrinth invokes a sensation of turning inward then outward, perhaps reminding us of our first journey from our mother's body into the world" (Introduction iv, 2010).

In her most recent book, Ancient Map for Modern Birth (England 2017), England broadens her discussion of labyrinths for birth to include sections on ceremonies and various rituals to use during pregnancy, birth, and the postpartum period. These include the construction of a birth altar for the mother or parents and the baby, the making of birth art during pregnancy, and the practice of breathing and visualization techniques often associated with Chinese Daoism. In all cases, these rituals have the capacity to become sacred in the context of birth as a rite of passage, religious or nonreligious. 


\subsubsection{Silas Kayakjuak's Birth Sculptures}

Silas Kayakjuak is an artist who began representing the event of birth during the twentieth century (Kayakjuak n.d.). His carvings have become more recognized into the twenty-first century, however, particularly within the birth community (Kayakjuak 2017). An Inuit artist from the Nunavut Territory of Canada, Kayakjuak comes from a family of carvers. He has carved many images of the human form into stone over the course of his career, and the themes of pregnancy, birth, and mothering recur in his work. There is a warmth and calmness to his carvings, found also in this small sculpture of a woman giving birth. In Kayakjuak's piece, Birthing the Old Way (Figure 4), the crowning baby emerges fully from the woman's form while her facial expression remains strong but serene. The woman's entire body concentrates on the birth of the baby, pressing forward and resting in a squatting position. Carved in serpentine, the sculpture is round and smooth, adding a tactile element to its sense of calmness. In our correspondences, Kayakjuak explained that the title of the work refers to the natural birth without medical intervention (Kayakjuak 2017).

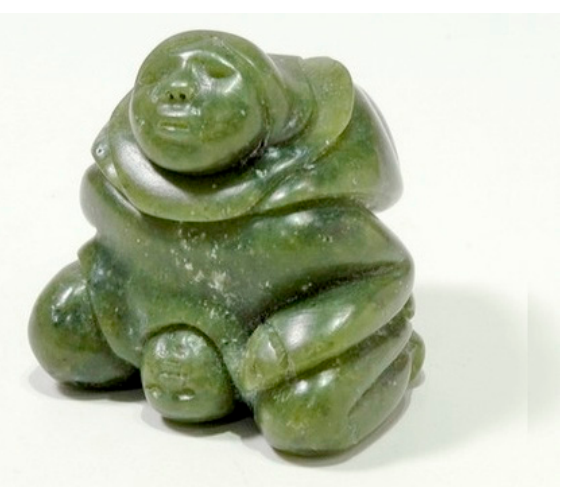

Figure 4. Birthing the Old Way, serpentine carving. Copyright 1995, Silas Kayakjuak, used with permission.

Scholars Claire Dion Fletcher and Cheryllee Bourgeois describe the sacredness that is at the heart of Indigenous birth practices in their book chapter, "Refusing Delinquency, Reclaiming Power: Indigenous Women and Childbirth" (Fletcher and Bourgeois 2015):

"Pregnancy and birth are sacred events in Indigenous communities. Pregnant women are to be honored and cared for in their role in continuing the life of the family and community ... Women are considered to have a deeper connection to the spirit world when they are pregnant because of the spirit they are growing and caring for. Birth is understood as a ceremony in itself" (154).

Reflecting on his understanding of this sense of the sacred, Kayakjuak carves new work devoted to providing images of the birth event as a sacred event. Referencing the work of Kayakjuak and other Indigenous artists, Fletcher and Bourgeois point to the empowerment and sacredness that these contemporary images of birth provide to those who view them:

"Work such as the sculptures of Inuit artists Silas Kayakjuak and Mary Oashutsiaq depict Inuit women giving birth-babies quite literally at the threshold of new life with their heads born while the rest of the body is not yet out. These birth scenes with women helping other women place the experience and control of that moment in the hands of Inuit women. Paintings by Potawatomi artist Daphne Odjig and Metis artist Leah Dorian depict pregnancy, motherhood, and birth scenes firmly rooted in Indigenous perspectives, including physical and spiritual understandings of these experiences" (165).

While the sacredness represented in Kayakjuak's work is intimately connected to Inuit traditions, the artist refers to the representation as a piece that simply shows birth more generally as it has occurred in the past, before the arrival of medical intervention in the 
birth process. For Kayakjuak, the act of birth is sacred in itself. The sense of the carving's sacredness also derives from the viewers' collective nonreligious understanding that birth is a sacred event. Kayakjuak's artwork holds special meaning and power within the Inuit community. As our world becomes globalized, however, members of the international birth community view the artist's work as sacred when seeking out representations of the birthing process. For some, Kayakjuak's carvings of the event therefore celebrate birth as a sacred event in itself.

\subsubsection{A Merging of Justice and the Sacred in the Painting of Anoa Kanu}

Artist Anoa Kanu is a Harlem-based water-media artist. She is also a Registered Nurse and a certified lactation consultant, and some of her artwork pertains to the theme of birth. The figures she depicts often include references to the sacredness of the pregnant or birthing form, as well as to how birth is connected to themes of justice for women, and especially marginalized women. In Kanu's Girl in Bamboo Earrings (Figure 5), the main figure squats amid lush vegetation, supported by warm brown shoots of bamboo behind her. Cradling her belly, the woman's arms and hands arch down and draw the viewer's attention to the soft swirl of a crowning baby at her vulva. She remains completely serene during this process of birth and emergence, her facial expression focused and calm. Her body and its processes are part of the natural world. The painting emphasizes the squatting position, an ideal manner of utilizing gravity as a natural aid in delivering one's baby. Unassisted in the birth, the main figure also reminds other pregnant women that they are part of a long lineage of women who have birthed before.

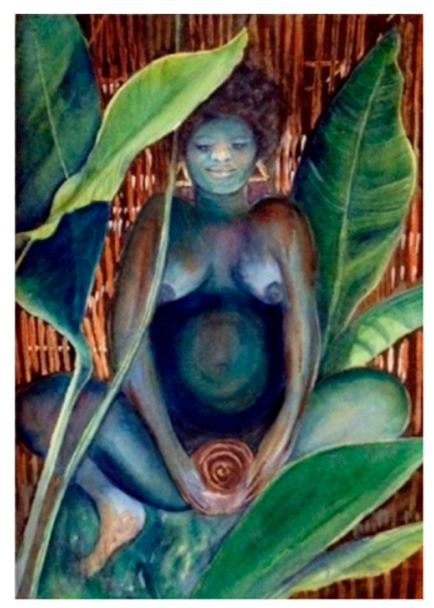

Figure 5. Girl in Bamboo Earrings, watercolor.

In our correspondences, Kanu described the making of this image, and her words about its creation and meaning are powerful in understanding how the themes of both the sacred and justice are integral to her work. Kanu describes the empowerment of the marginalized and an ability to transcend space and time during the birth event. This explanation of birth is not related to an experience of the mundane world but of one inspired by a sense of awe, timelessness, and the sacred:

"I am a painter, but I also work in women's health with new mothers and babies in an urban environment. I see a lot of beauty, new life, beginnings. But I also see a lot of disempowerment, young women not knowing their rights, what questions to ask or that they could even ask."

"When I imagined this image in my mind's eye, I saw a young woman, birthing for the first time, knowing she was capable, transcending space and time. She is protected and is able to tap into her elemental self and ancestral memory. She transforms through the birth process into a new being, a more fully empowered version of herself." 
"The first birth I had ever been to was a water birth, it was like this. The midwife was not intrusive. The mother was fully committed to the natural birth process. The spirit of the birth environment was palpable and womblike itself. She was mostly quiet but also moaned and grunted when she needed to. She moved as she wished. It was clear she had gone into a very deep place within herself. At the very end, she let out the most guttural of sounds. She birthed her baby. She was not delivered."

"Not every birth will be like this, there is no one way. But I know this exists, that it is possible. Reclaiming birth is an essential part of our liberation."

\section{(Kanu 2016, email correspondence)}

For Kanu, when a laboring woman is provided a safe environment in which she can go into a deeper place and realize birth as a timeless, sacred event, the woman's physiological processes have a better chance of unfolding. In this sacred space of birth, the woman is transformed, empowered, and liberated.

Kanu's work is especially pertinent in the context of how sacred images of birth are important for marginalized women. More broadly, however, Kanu represents the event of birth as a humanistic and nonreligious act that is sacred in itself.

\section{Conclusions}

With the art and other objects mentioned in this paper, there is spectrum of cultural appropriation occurring. In some cases, the item is created within its own cultural context; in others, there may be some level of connection to the original cultural context; and in others, connection to the original context is limited to as it occurs through the acts of birth or mothering. Contemporary artists working on the topic of childbirth are by nature living in a globalized community and in many cases influenced by traditions that may have a positive impact on the birth experiences of those who are pregnant or part of the contemporary rituals of birth. Whether those working in the birth community should have the right to utilize images that do not stem from their own tradition is an interesting moral question in need of a separate study and much more examination. As I discuss in my book, Imagery, Ritual, and Birth, however, moral categorization is complex when it comes to cultural appropriation in the context of childbirth, especially as the issue relates to physiological transformation and the bettering of health for those who are pregnant, giving birth, or in a postpartum condition.

There are many other examples of art and material culture that depict themes of birth and are deemed as "sacred." In our globalized world, many of these images are widely accessible through website collections, museums, and online galleries, as well as in person through local birth and medical communities. This paper has pointed to evidence that some of these objects historically identified as religious have been re-sacralized within the contemporary rituals of birth. Furthermore, in other cases where the objects are entirely of a nonreligious nature, artists or members of the birth community may present the items as sacred from the outset. This sacredness is based exclusively on the artwork's relationship to the humanistic act of birth as a rite of passage.

This research demonstrates how participants in the contemporary rituals of birth view art and other objects related to the processes of pregnancy, labor, birth, mothering, and parenting as sacred objects. While the artists of these works sometimes utilize religious iconography, they are not replicating an original religious object. Instead, they are creating brand-new work in which the human self who births or parents is represented as a sacred self.

Funding: This research received no external funding.

Institutional Review Board Statement: Not applicable.

Informed Consent Statement: Not applicable.

Data Availability Statement: Not applicable. 
Conflicts of Interest: The author declares no conflict of interest.

\section{References}

Black, Christopher F., and Pamela Gravestock. 2003. Early Modern Confraternities in Europe and the Americas: International and Interdisciplinary Perspectives. Aldershot and Burlington: Ashgate.

Bolin, Inge. 1998. Rituals of Respect: The Secret of Survival in the High Peruvian Andes. Austin: University of Texas Press.

Bolin, Inge. 2006. Growing up in a Culture of Respect: Child Rearing in Highland Peru. Austin: University of Texas Press.

Cheyney, Melissa. 2011. Reinscribing the Birthing Body: Homebirth as Ritual Performace. Medical Anthropology Quarterly 25: 519-42. [CrossRef] [PubMed]

Cole, Herbert M. 2017. Maternity: Mothers and Children in the Arts of Africa. Brussels: Mercatorfonds.

Cole, Herbert M. 2018. Exploring Motherhood in African Arts. İmò Dára. April 6. Available online: https://www.imodara.com/ magazine/exploring-motherhood-in-african-arts/ (accessed on 29 August 2018).

Cooper, Gene. 1998. Life-Cycle rituals in Dongyang County: Time, affinity, and exchange in rural China. Ethnology 4: 373-94. [CrossRef]

Curry, Helen. 2000. The Way of the Labyrinth: A Powerful Meditation for Everyday Life. London: Penguin Books.

Davis-Floyd, Robbie. 1992. Birth as an American Rite of Passage. Berkeley, Los Angeles and London: University of California Press.

de Andrade, Yohana. 2014. How to Empower Women through Religion. Global Economic Symposium Blog. Available online: http:/ /blog.global-economic-symposium.org/how-to-empower-women-through-religion/ (accessed on 12 April 2017).

de la Croix, Horst, Diane Kirkpatrick, and Richard G. Tansey. 1991. Art Through the Ages, 9th ed. San Diego, New York, Chicago, Austin, Washington, DC, London, Sydney, Tokyo and Toronto: Harcourt Brace Jovanovich Publishers.

England, Pam. 2010. Labyrinth of Birth: Creating a Map, Meditations and Rituals for your Childbearing Year. Birthing From Within Books. Albuquerque: Partera Press.

England, Pam. 2017. Ancient Map for Modern Birth. Albuquerque: Seven Gates Media.

Fletcher, Claire Dion, and Cheryllee Bourgeois. 2015. Refusing Delinquency, Reclaiming Power: Indigenous Women and Childbirth. In Natal Signs: Cultural Representations of Pregnancy, Birth and Parenting. Edited by Nadya Burton. Bradford: Demeter Press, pp. 153-71.

Geertz, Clifford. 1973. The Interpretation of Culture. New York: Basic Books.

Gómez, Campos, and Juan Carlos. 2016. Los Laberintos Prehistóricos del Monte Teleno. Argutorio 36: 1-10.

Hennessey, Anna. 2010. Visualizing Birth Image Archive. Available online: visualizingbirth.org (accessed on 26 July 2011 ).

Hennessey, Anna. 2017. How Childbirth Became Philosophy's Last Taboo. The Institute of Art and Ideas. August 10. Available online: https:/ / iainews.iai.tv/articles/why-do-the-arts-put-death-before-birth-auid-867 (accessed on 26 July 2011).

Hennessey, Anna. 2018. Imagery, Ritual, and Birth: Ontology Between the Sacred and the Secular. an imprint of Rowman \& Littlefield. Lanham: Lexington Books.

Kanu, Anoa. 2016. email correspondence with author. September 27.

Kassamali Rickicki, Sorayya. 2017a. email correspondence with author. April 15 and 22.

Kassamali Rickicki, Sorayya. 2017b. Pachamama Birth. Available online: http://www.pachamamabirth.com/about/ (accessed on 12 April 2021).

Kayakjuak, Silas. 2017. Author email correspondence with artist's representative, Ian Wright. June 27.

Kayakjuak, Silas. n.d. Available online: http://snowgoose.ca/Silas/silas1.htm (accessed on 26 July 2011).

Kirwen, Michael C. 2004. African Cultural Domain No. 1: Pregnancy and Birthing Rites and Rituals. Nairobi: Maryknoll Institute of African Studies.

Klassen, Pamela E. 2001. Blessed Events: Religion and Homebirth in America. Princeton and Oxford: Princeton University Press.

Lugones Botell, Miguel, and Marieta Ramirez Bermudez. 2012. El parto en diferentes posiciones a través de la ciencia, la historia y la cultural. Revista Cubaba de Obstetricia y Ginecología 38: 1.

Lynch, Gordon. 2012. On the Sacred. Durham: Acumen.

Paris, Eva. 2011. Partos verticales en el arte prrecolombino. Bebés y más. Available online: https://www.bebesymas.com/parto/partosverticales-en-el-arte-precolombino (accessed on 12 April 2017).

Paris, Eva. 2017. El Parto en La Historia. Available online: http:/ / maternatalmadrid.blogspot.com/2014/07/el-parto-en-la-historia. html (accessed on 12 April 2014).

Taussig, Michael. 2010. The Devil and Commodity Fetishism in South America. 30th Anniversary Issue. Chapel Hill: The University of North Carolina Press.

van Gennep, Arnold. 1960. The Rites of Passage (Les Rites de Passage, 1909). Chicago: University of Chicago Press.

Werness, Hope B. 2000. Continuum Encyclopedia of Native Art: Worldview, Symbolism, and Culture in Africa, Oceania, and Native North America. New York and London: Continuum.

Wilford, John Noble. 2009. Full-Figured Statuette, 35,000 Years Old, Provides New Clues to How Art Evolved. The New York Times. May 13. Available online: http:/ /www.nytimes.com/2009/05/14/science/14venus.html (accessed on 22 May 2017).

Williams, Ogechukwu Ezekwem. 2018. A Blur between the Spiritual and the Physical: Birthing Practices among the Igbo of Nigeria in the Twentieth Century. In Sacred Inception: Reclaiming the Spirituality of Birth in the Modern World. Edited by Marianne Delaporte and Morag Martin. Lanham: Lexington Books, pp. 97-112. 